\title{
Evaluation of healthcare associated infections at pediatric critical care units
}

\section{Çocuk yoğun bakım üinitesinde saptanan hastane enfeksiyonlarının retrospektif olarak değerlendirilmesi}

\author{
Ebru Atike Ongun ${ }^{1}$, Ahu Aksay2
}

\begin{abstract}
${ }^{1}$ Cumhuriyet University, Faculty of Medicine, Department of Pediatrics, Division of Pediatric Critical Care, Sivas, Turkey
${ }^{2}$ Cumhuriyet University, Faculty of Medicine, Department of Pediatrics, Division of Pediatric Infectious Diseases, Sivas, Turkey

Corresponding author: Ebru Atike Ongun, MD, Cumhuriyet University, Faculty of Medicine, Department of Pediatrics, Division of Pediatric Critical Care, Sivas, Turkey

E-mail: ebru_temel@yahoo.com

Received/Accepted: March 21, 2019 / March 26, 2019

Conflict of interest: There is not a conflict of interest.
\end{abstract}

\begin{abstract}
Objective: Health-care associated infection (HAI) constitutes a major health care problem resulting in prolonged hospital stay with increased medical costs. The burden is much greater by accompanying risk factors among intensive care admissions. The incidence is reported $30 \%$ of all ICU admissions in developed countries; however the estimated rates are clearly higher in developing countries ${ }^{3}$.

In order to prevent HAIs, the health-care facilities should determine their own risk factors, analyse the microorganisms isolated from the body fluids and provide the necessary precautions accordingly ${ }^{5}$. Despite all the efforts and the advances at preventive protocols, the HAI burden still exits.

The pediatric intensive care unit (PICU) of Sivas Cumhuriyet University Hospital is a tertiary critical care unit serving to a broad range of population under 18 years with highly advanced technology within a considerably populated territory. The demographic profiles of the admissions account a wide range of childhood sicknesses from trauma to neurological disorders. The aim of this retrospective study was to examine the microorganism profiles isolated from the body fluids (blood, urine, tracheal aspirates, wound cultures, spinal fluid) of all PICU admissions during the past five years. Hence we decided to obtain our local surveillance data, deploy the necessary precautions to decline HAIs and administer the appropriate antimicrobial therapy accordingly.
\end{abstract}

Method: In this retrospective descriptive study, we searched the medical records of all PICU admissions between January 2014 and December 2018. Children with i) PICU admission lasting over 48 hours, ii) culture positiviy at body fluids, iii) presenting clinical signs of infection were enrolled in the study. Patient demographics, initial complaints, admission diagnosis, the underlying chronical conditions, the source of PICU admission (admission from an indoor clinic, emergency service or an outdoor clinic) and previous hospitalizations were all recorded. We recalled HAI subgroups according to the definitions of centers for disease control and prevention (CDC) ${ }^{6}$ such as: ventilator-associated pneumonia (VAP), blood stream infection (BSI), central line-associated bloodstream infections (CLABSIs), catheterassociated urinary tract infections (CAUTI) and surgical site infections (SSI).

SPSS-23 (Statistical Package for Social Sciences for Windows 23) was used for statics of the study. Descriptive analyses were expressed as percentages, mean \pm standart deviation (SD), median with minimum and maximum values. Chi square and Fischer exact test were used for comparison of categorical variables. Normal and non-normal distributions of continous variables were assessed by Student's t-test, Mann Whitney U test and Wilcoxon rank sum test. P-value < 0.05 was considered significant.

Results: Investigation of 1566 PICU admissions between the periods January 2014 and December 2018, presented 56 children with 71 culture positivity at body fluids (infection rate:4.5\%). The median age was 15 months (2 months-17 years) and male gender occupied $58.9 \%$ of the study population. We observed respiratory distress and acute pneumonia as the major complaint and the diagnosis at admission (48.5\% and 35.7\% respectively). $76.7 \%$ of the children manifested previous hospitalizations. Forty-three children presented an underlying chronical condition; mainly involving the central nervous system. The sources of PICU admission were identified as: first admission from the emergency service (44.6\%), an outdoor clinic (28.6\%) and an indoor clinic (pediatric ward) $(26.8 \%)$.

In terms of culture positivity, we observed PICU-infections as (in decreasing order): VAP (26/71, 36.6\%), BSI (18/71, 25.4\%), CAUTI (18/71, 25.4\%), SSI (7/71, 9.9\%) and CLABSIs (2/71, 2.8\%). Infections with gram-negative bacteria constituted the major infection group (54/71, 77.1\%); Acinetobacter baumanii and Klebsiella pneumonia seemed as the 
most frequent isolated microorganisms (25.3\% and 14.1\%). Fungi infections incapsulated $12.6 \%$ of the infections overall. Amog the thirty $(42.2 \%)$ antibiotic resistant-culture positivity, carbapenem resistant and ESBL positive bacteria occured as the common strains $(21.1 \%$ and $12.7 \%$ respectively). We observed Carbapenem resistant strains mostly at SSI (5/15, $33.3 \%$ ), while ESBL positive strains were developed at BSI and CAUTI.

In terms of ventilator-associated events, the mean intubation length was $17.5 \pm 5.4$ days. Pseudomonas aeruginosa ve Acinetobacter baumanii were the most common bacterias reproduced at tracheal aspirates. For the resistance strains, Colistin-resistant Acinetobacter baumanii demonstrated the most prominent resistant strain at a rate of 50\%, followed by Carbapenem-resistant strains (15.4\%). Colistin-resistant strains seemed to have an escalating trend especially in 2018, on the contrary the frequency of carbapenem-resistant strains have declined over ther years.

Length of PICU stay and hospitalization were $38.1 \pm 27.6$ days and $42.2 \pm 27.6$ days respectively. Twelve children died of infections (21.4\%). Age less than five years and higher PRISM-3 scores were associated with mortality $(\mathrm{p}=0.004$ and $\mathrm{p}<0.001)$. Those who died had longer intubation, PICU stay and hospitalization periods with significant nasogastric tube insertion rates (in following order, $\mathrm{p}=0.007, \mathrm{p}=0.010, \mathrm{p}=0.045, \mathrm{p}=0.001$ ).

Conclusions: Health-care associated infections remain to be a major problem all around the world. What we can do to overcome this challenge is, to initiate local survaillance protocols, educate the health-care stuff on hand hygiene, enforce appropriate isolation tactics and practice wise antibotic administration.

Keywords: Health-care associated infection, pediatric critical care, ventilator-associated pneumonia, central lineassociated bloodstream infections, catheter-associated urinary tract infections

\section{ÖZET}

Amaç: Hastane enfeksiyonları (HE), hastalarda hastaneye başvuru anında veya inkübasyon döneminde olmayan, hastaneye başvurularından 48-72 saat sonra gelişen enfeksiyonlar olarak tanımlanmaktadır. Bu çalışmada çocuk yoğun bakım ünitemizin HE açısından lokal sürveyans verilerinin elde edilmesi, HE sıklığının azaltılması ve uygun tedavinin gecikmeden uygulanabilmesi amaçlanmıştır.

Yöntem: Sivas Cumhuriyet Üniversitesi Hastanesi Çocuk Yoğun Bakım(ÇYB) servisine Ocak2014-Aralık2018 tarihleri arasında yatan hastaların geriye dönük dosyaları incelendi. HE tanımlamaları "Centers for Disease Control and Prevention" kriterlerine göre değerlendirildi.

Bulgular: Çalışma süresince yatmış olan 1566 hastanın (7651 yoğun bakım yatış günü) toplam 56'sında, 71 HE saptandı (enfeksiyon hızı:\%4.5). Ortanca yaş 15 ay (2ay-17yaş), E/K:1.43 olarak gözlendi. Solunum sıkıntısı ve pönomoni en sık başvuru şikâyetini ve yatış tanısını oluşturdu (\%48.5,\%35.7). HE yeri olarak, azalan sıklıkla VİO (26/71, \%36.6), KDE (18/71, \%25.4), ÜSE (18/71, \%25.4), CAE (7/71, \%9.9), SVK-KDE (2/71, \%2.8) görüldü. Gram negatif bakteri enfeksiyonlarının belirgin olduğu çalışmada (54/71, \%77.1), Acinetobacter baumanii ve Klebsiella pneumonia en sik bakteriyel etkenlerdi (\%25.3, \%14.1). Çalışmamızda funguslar HE'nin \%12.6'sından sorumlu bulundu. Antibiyotik direncinin 30 kültür üremesinde var olduğu (\%42.2), karbapenem direnci (\%21.1) ile ESBL (\%12.7) pozitif bakteri oranının en sık iki antibiyotik direncini oluşturduğu gözlendi. On iki hasta enfeksiyona ikincil sebeplerden eksitus oldu (HE mortalite oranı: \%21.4). Eksitus olan hastaların 5 yaşından küçük, yüksek PRISM skoruna, uzun entübasyon süresine, sık nazogastrik sonda uygulamasına, uzun yoğun bakım ve hastane yatış sürelerine sahip oldukları görüldü $\quad$ (sırasıly $\quad$ p=0. 004, $\mathrm{p}<0.001, \mathrm{p}=0.007, \mathrm{p}=0.001, \mathrm{p}=0.010, \mathrm{p}=0.045)$.

Sonuç: Hastane enfeksiyonları, hastane yatış süresini uzatan, tedavi maliyetleri ile morbidite ve mortalitesi yüksek olan enfeksiyonlardır. İnvazif girişimlerin yoğun olduğu, kritik hasta takibinin yapıldığı çocuk yoğun bakım servislerinde ise, diğer risk faktörlerinin de eklenmesi ile HE riski ve sıklığı belirgin olarak artar. Bu nedenle yoğun bakım ünitelerinde sürveyans çalışmaları yapılarak uygun tedavinin başlanması sağlanmalı ve gereksiz invaziv girişimleri azaltarak hastane enfeksiyonu nedeniyle oluşan morbidite ve mortalite azaltılmalıdır.

Anahtar sözcükler: Çocuk yoğun bakım, hastane enfeksiyonu, antibiyotik direnci

\section{INTRODUCTION}

Health-care associated infection (HAI) constitutes a major health care problem resulting in prolonged hospital stay with increased medical costs $^{1}$. The burden is much greater by accompanying risk factors among intensive care $\operatorname{admissions}^{2-4}$. The incidence is reported $30 \%$ of all ICU admissions in developed countries; however the estimated rates are clearly higher in developing countries ${ }^{3}$.

In order to prevent HAIs, the health-care facilities should determine their own risk factors, analyse the microorganisms isolated from the body fluids and provide the necessary precautions accordingly ${ }^{5}$. Despite all the efforts and the advances at preventive protocols, the HAI burden still exits.

The pediatric intensive care unit (PICU) of Sivas Cumhuriyet University Hospital is a tertiary critical care unit serving to a broad range of population under 18 years with highly advanced technology within a considerably populated territory. The demographic profiles of the admissions account a wide range of childhood 
sicknesses from trauma to neurological disorders. The aim of this retrospective study was to examine the microorganism profiles isolated from the body fluids (blood, urine, tracheal aspirates, wound cultures, spinal fluid) of all PICU admissions during the past five years. Hence we decided to obtain our local surveillance data, deploy the necessary precautions to decline HAIs and administer the appropriate antimicrobial therapy accordingly.

\section{MATERIAL AND METHODS}

In this retrospective descriptive study, we searched the medical records of all PICU admissions between January 2014 and December 2018. Children with i) PICU admission lasting over 48 hours, ii) culture positiviy at body fluids, iii) presenting clinical signs of infection were enrolled in the study. Patient demographics, initial complaints, admission diagnosis, the underlying chronical conditions, the source of PICU admission (admission from an indoor clinic, emergency service or an outdoor clinic) and previous hospitalizations were all recorded. In case of multiple culture positiviy at different body fluids, each one of the isolated microorganisms were enlisted seperately (they were referred as children with multiple culture positivity). We recalled HAI subgroups according to the definitions of centers for disease control and prevention $(\mathrm{CDC})^{6}$ such as: ventilator-associated pneumonia (VAP), blood stream infection (BSI), central line-associated bloodstream infections (CLABSIs), catheter-associated urinary tract infections (CAUTI) and surgical site infections (SSI). The microorganisms with antibotic resistance were categorized as: methicillinresistant Staphylococcus aureus (MRSA), methicillin-resistant coagulase negative Staphylococcus (CoNS), bacteria producing extended-spectrum beta-lactamases (ESBL), Carbapenem-resistant bacteria, and Colistin- resistant Acinetobacter baumanii. We determined the infection rate by dividing the number of culture-positive children to the total number of PICU admissions, then multiplied with 100.

We obtained approval of the noninvasive clinical research ethics committe of Sivas Cumhuriyet University.

SPSS-23 (Statistical Package for Social Sciences for Windows 23) was used for statics of the study. Descriptive analyses were expressed as percentages, mean \pm standart deviation (SD), median with minimum and maximum values. Chi square and Fischer exact test were used for comparison of categorical variables. Normal and non-normal distributions of continous variables were assessed by Student's t-test, Mann Whitney $\mathrm{U}$ test and Wilcoxon rank sum test. $\mathrm{P}$-value $<0.05$ was considered significant.

\section{RESULTS}

Investigation of 1566 PICU admissions between the periods January 2014 and December 2018, presented 56 children with 71 culture positivity at body fluids (infection rate:4.5\%). The median age was 15 months (2 months-17 years) and male gender occupied $58.9 \%$ of the study population. We observed respiratory distress and acute pneumonia as the major complaint and the diagnosis at admission $(48.5 \%$ and $35.7 \%$ respectively). Table 1 represents the initial compliants and admission diagnosis. $76.7 \%$ of the children manifested previous hospitalizations. Forty-three children presented an underlying chronical condition; mainly involving the central nervous system (Table 2). The sources of PICU admission were identified as: first admission from the emergency service $(44.6 \%)$, an outdoor clinic (28.6\%) and an indoor clinic (pediatric ward) $(26.8 \%)$. 
Table 1. Initial complaints and the diagnosis of PICU admissions

\begin{tabular}{|lc|lc|}
\hline Initial compliants & $\boldsymbol{n}(\mathbf{6 6})^{*}$ & Initial diagnosis & $\boldsymbol{n}(\mathbf{5 6})^{*}$ \\
\hline Respiratory distress & $32(48.5 \%)$ & Acute pneumonia & $20(35.7 \%)$ \\
Fever & $12(18.2 \%)$ & Sepsis & $9(16.0 \%)$ \\
Seizure & $11(16.7 \%)$ & Status epilepticus & $8(14.3 \%)$ \\
Loss of consciousness & $2(3.0 \%)$ & Ventriculo-peritoneal shunt (VP) & $6(10.7 \%)$ \\
Trauma & $4(6.0 \%)$ & Trauma / gunshot injury & $5(8.9 \%)$ \\
Burns & $2(3.0 \%)$ & Postoperative infection & $2(3.6 \%)$ \\
Gunshot injury & $1(1.5 \%)$ & Burns & $2(3.6 \%)$ \\
Intoxicity & $1(1.5 \%)$ & Acute kidney failure & $1(1.8 \%)$ \\
İnability to urinate & $1(1.5 \%)$ & Cardiomyopathy & $1(1.8 \%)$ \\
& & Soft tissue infection & $1(1.8 \%)$ \\
& & Intoxication (Suicide) & $1(1.8 \%)$ \\
\hline
\end{tabular}

*In case of multiple compliants, each one them were recorded and categorized seperately.

Table 2. The underlying chronical conditions

\begin{tabular}{|l|c|}
\hline & $(\boldsymbol{n = 4 3})$ \\
\hline Cerebral palsy / Epilepsy & $12(27.9 \%)$ \\
\hline Hydrocephalus/ VP shunting & $14(32.5 \%)$ \\
\hline Immune deficiency & $6(10.7 \%)$ \\
\hline Cardiomyopathy & $2(4.6 \%)$ \\
\hline Chronic kidney failure & $2(4.6 \%)$ \\
\hline Congenital hydrops fetalis & $2(4.6 \%)$ \\
\hline Metabolic disease & $2(4.6 \%)$ \\
\hline Genetic anomaly (Pierre Robin syndrome) & $1(2.3 \%)$ \\
\hline Rheumatological disorder & $1(2.3 \%)$ \\
\hline Gastrointestinal system disease & $1(2.3 \%)$ \\
\hline
\end{tabular}


In terms of culture positivity, we observed PICUinfections as (in decreasing order): VAP (26/71, $36.6 \%)$, BSI $(18 / 71,25.4 \%)$, CAUTI $(18 / 71$, $25.4 \%)$, SSI $(7 / 71,9.9 \%)$ and CLABSIs $(2 / 71$, $2.8 \%$ ). Table 3 presents the microorganism isolated from the body fluids and the area of infection. Infections with gram-negative bacteria constituted the major infection group (54/71, 77.1\%); Acinetobacter baumanii and Klebsiella pneumonia seemed as the most frequent isolated microorganisms $(25.3 \%$ and $14.1 \%)$. Fungi infections incapsulated $12.6 \%$ of the infections overall.
Amog the thirty (42.2\%) antibiotic resistantculture positivity, carbapenem resistant and ESBL positive bacteria occured as the common strains (21.1\% and $12.7 \%$ respectively). We observed Carbapenem resistant strains mostly at SSI (5/15, $33.3 \%$ ), while ESBL positive strains were developed at BSI and CAUTI (Table 3).

Table 3. The isolated microorganisms and the location of infections

\begin{tabular}{|c|c|c|c|c|c|c|}
\hline Isolated microorganisms & $\begin{array}{c}\text { BSI } \\
(n=18)\end{array}$ & $\begin{array}{l}\text { CAUTI } \\
(n=18)\end{array}$ & $\begin{array}{l}\text { VAP } \\
(n=26)\end{array}$ & $\begin{array}{c}\text { SSI } \\
(n=7)\end{array}$ & $\begin{array}{l}\text { CLABSI } \\
(n=2)\end{array}$ & $\begin{array}{l}\text { Toplam } \\
\text { n (71) }\end{array}$ \\
\hline \multicolumn{6}{|l|}{ Bacterial infections } & $\begin{array}{c}62 \\
(87.3 \%) \\
\end{array}$ \\
\hline \multicolumn{7}{|c|}{ Gram negative bacteria } \\
\hline Acinetobacter baumanii & 3 & 4 & 4 & 5 & 2 & $18(25.3 \%)$ \\
\hline Klebsiella pneumonia & 3 & 4 & 3 & - & - & $10(14.1 \%)$ \\
\hline Pseudomonas aeruginosa & 1 & - & 7 & - & - & $8(11.3 \%)$ \\
\hline Stenotrophomonas maltophilia & 2 & - & 4 & - & - & $6(8.5 \%)$ \\
\hline Serratia marcescens & - & 1 & 4 & - & - & $5(7.1 \%)$ \\
\hline Enterobacteriaceae & 1 & 1 & 1 & - & - & $3(4.2 \%)$ \\
\hline Escherichia coli & - & 2 & - & 1 & - & $3(4.2 \%)$ \\
\hline Burkholderia cepacia & 1 & - & - & - & - & $1(1.4 \%)$ \\
\hline \multicolumn{7}{|c|}{ Gram positive bacteria } \\
\hline Staphylococcus aureus & 1 & - & 1 & - & - & $2(2.8 \%)$ \\
\hline Staphylococcus epidermidis & 1 & - & - & 1 & & $2(2.8 \%)$ \\
\hline Enterococcus faecium & - & 2 & - & - & - & $2(2.8 \%)$ \\
\hline Streptococcus mitis & 1 & - & - & - & - & $1(1.4 \%)$ \\
\hline Streptococcus salivarius & 1 & - & - & - & - & $1(1.4 \%)$ \\
\hline \multicolumn{7}{|l|}{$\begin{array}{l}\text { Fungi } \\
9(16.7 \%) \\
\end{array}$} \\
\hline Candida albicans & 1 & 3 & 1 & - & - & $5(7 \%)$ \\
\hline Candida saprophyticus & 1 & - & 1 & - & - & $2(2.8 \%)$ \\
\hline Candida glabrata & - & 1 & - & - & & $1(1.4 \%)$ \\
\hline Candida tropicalis & 1 & - & - & - & - & $1(1.4 \%)$ \\
\hline
\end{tabular}

Antibiotic Resistant Strains

\begin{tabular}{|l|c|c|c|c|c|c|}
\hline Carbapenem resistance & 2 & 4 & 4 & 5 & - & $15(21.1 \%)$ \\
\hline ESBLproducing bacteria & 3 & 3 & 2 & 1 & - & $9(12.7 \%)$ \\
\hline Colistin resistant A. baumanii & 1 & - & 2 & - & - & $3(4.2 \%)$ \\
\hline MRSA & 1 & - & 1 & - & - & $2(2.8 \%)$ \\
\hline Meticilline resistant CoNS & & & & 1 & - & $1(1.4 \%)$ \\
\hline
\end{tabular}

VAP: ventilator-associated pneumonia (VAP), BSI: blood stream infection, CLABSI: central line-associated bloodstream infection, CAUTI: catheter-associated urinary tract infections, SSI: surgical site infection. 
In terms of ventilator-associated events, the mean intubation length was $17.5 \pm 5.4$ days. Pseudomonas aeruginosa ve Acinetobacter baumanii were the most common bacterias reproduced at tracheal aspirates (Table 3). For the resistance strains, Colistin-resistant Acinetobacter baumanii demonstrated the most prominent resistant strain at a rate of $50 \%$, followed by Carbapenem-resistant strains (15.4\%). Colistinresistant strains seemed to have an escalating trend especially in 2018, on the contrary the frequency of carbapenem-resistant strains have declined over ther years (Table 4). The locations of antibotic resistant infections for Colistinresistant Acinetobacter baumanii and ESBL positive Klebsiella pneumonia were identified as BSI and CLABSI.

Length of PICU stay and hospitalization were $38.1 \pm 27.6$ days and $42.2 \pm 27.6$ days respectively. Twelve children died of infections (21.4\%). Age less than five years and higher PRISM-3 scores were assciated with mortality $(\mathrm{p}=0.004$ and $\mathrm{p}<0.001)$. Those who died had longer intubation, PICU stay and hospitalization periods with significant nasogastric tube insertion rates (in following order, $\mathrm{p}=0.007, \mathrm{p}=0.010, \mathrm{p}=0.045$, $\mathrm{p}=0.001)$ (Table 5).

Table 4. The isolated microorganisms over the past five years

\begin{tabular}{|c|c|c|c|c|c|c|}
\hline & 2014 & 2015 & 2016 & 2017 & 2018 & $(n=71)$ \\
\hline \multicolumn{7}{|l|}{ Bacteria $(n=62)$} \\
\hline \multicolumn{7}{|c|}{ Gram Negative Bacteria } \\
\hline Acinetobacter baumanii & - & 7 & 7 & - & 4 & $18(25.3 \%)$ \\
\hline Klebsiella pneumonia & 2 & 1 & 1 & 3 & 3 & $10(14.1 \%)$ \\
\hline Pseudomonas aeruginosa & 5 & 1 & 1 & 1 & - & $8(11.3 \%)$ \\
\hline Stenotrophomonas maltophilia & 2 & 2 & - & 1 & 1 & $6(8.5 \%)$ \\
\hline Serratia marcescens & 2 & 1 & 1 & 1 & - & $5(7.1 \%)$ \\
\hline Enterobacteriaceae & - & 2 & - & 1 & 0 & $3(4.2 \%)$ \\
\hline Escherichia coli & 2 & - & - & 1 & - & $3(4.2 \%)$ \\
\hline Burkholderia cepacia & - & - & - & 1 & - & $1(1.4 \%)$ \\
\hline \multicolumn{7}{|c|}{ Gram Positive Bacteria } \\
\hline Staphylococcus aureus & - & - & 1 & - & 1 & $2(2.8 \%)$ \\
\hline Staphylococcus epidermidis & 1 & - & - & 1 & - & $2(2.8 \%)$ \\
\hline Enterococcus faecium & - & - & - & 2 & - & $2(2.8 \%)$ \\
\hline Streptococcus mitis & - & - & - & - & 1 & $1(1.4 \%)$ \\
\hline Streptococcus salivarius & - & - & - & - & 1 & $1(1.4 \%)$ \\
\hline \multicolumn{7}{|l|}{ Fungi infections (n:9) } \\
\hline Candida albicans & 2 & 2 & - & 1 & - & $5(7.0 \%)$ \\
\hline Candida saprophyticus & 1 & 1 & - & - & - & $2(2.8 \%)$ \\
\hline Candida glabrata & - & - & - & - & 1 & $1(1.4 \%)$ \\
\hline Candida tropicalis & 1 & - & - & - & - & $1(1.4 \%)$ \\
\hline \multicolumn{7}{|c|}{ Antibiotic Resistance } \\
\hline Carbapenem resistance & & 4 & 6 & 2 & 2 & $15(21.1 \%)$ \\
\hline ESBLproducing bacteria & 4 & - & - & 2 & 3 & $9(12.7 \%)$ \\
\hline Colistin resistant A. baumanii & - & 1 & - & - & 2 & $3(4.2 \%)$ \\
\hline MRSA & & - & - & 1 & 1 & $2(2.8 \%)$ \\
\hline Meticilline resistant CoNS & & & & 1 & & $1(1.4 \%)$ \\
\hline
\end{tabular}

Table 5. The demographics and the intensive care interventions according to mortality 


\begin{tabular}{|c|c|c|c|}
\hline Variable & $\begin{array}{l}\text { Survivors } \\
(n=44)\end{array}$ & $\begin{array}{l}\text { Non-survivors } \\
(n=12)\end{array}$ & $p$ \\
\hline $\begin{array}{l}\text { Gender } \\
\text { Male } \\
\text { Female }\end{array}$ & $\begin{array}{l}24(54.5 \%) \\
20(45.5 \%)\end{array}$ & $\begin{array}{l}9(75 \%) \\
3(25 \%)\end{array}$ & 0.202 \\
\hline $\begin{array}{l}\text { Underlying chronical } \\
\text { condition }\end{array}$ & $33(75 \%)$ & $10(83.3 \%)$ & 0.210 \\
\hline Multiple culture positivity & $12(27.3 \%)$ & $6(50 \%)$ & 0.135 \\
\hline $\begin{array}{l}\text { Age (months), median (min- } \\
\text { max) }\end{array}$ & $15.50(1-197)$ & $12(2-197)$ & 0.562 \\
\hline $\begin{array}{l}\text { Age groups } \\
1 \text { month }-5 \text { years } \\
6-10 \text { years } \\
11-17 \text { years } \\
\end{array}$ & $\begin{array}{l}29(65.9 \%) \\
7(15.9 \%) \\
8(18.2 \%) \\
\end{array}$ & $\begin{array}{l}8(66.7 \%) \\
1(8.3 \%) \\
3(25 \%) \\
\end{array}$ & 0.004 \\
\hline $\begin{array}{r}\text { Years } \\
2018 \\
2017 \\
2016 \\
2015 \\
2014 \\
\end{array}$ & $\begin{array}{c}8(18.2 \%) \\
5(11.4 \%) \\
6(13.6 \%) \\
11(25 \%) \\
14(31.8 \%)\end{array}$ & $\begin{array}{l}2(16.7 \%) \\
1(8.3 \%) \\
3(25 \%) \\
3(25 \%) \\
3(25 \%)\end{array}$ & - \\
\hline PRİSM-3 score (mean $\pm S D$ ) & $12.65 \pm 3.22$ & $36.25 \pm 5.17$ & $<0.001$ \\
\hline $\begin{array}{l}\text { Length of PICU stay } \\
\text { (days) }(\text { mean } \pm S D)\end{array}$ & $31.54 \pm 24.67$ & $54.91 \pm 28.87$ & 0.010 \\
\hline $\begin{array}{l}\text { Length of hospitalization } \\
\text { (days) }(\text { mean } \pm S D)\end{array}$ & $37.0 \pm 25.85$ & $54.91 \pm 28.87$ & 0.045 \\
\hline \multicolumn{4}{|c|}{ PICU interventions } \\
\hline Endotracheal intubation & $26(59.1 \%)$ & $12(100 \%)$ & 0.007 \\
\hline $\begin{array}{l}\text { Central venous } \\
\text { catheterization }\end{array}$ & $24(54.5 \%)$ & $6(50 \%)$ & 0.780 \\
\hline Nasogastric tube insertion & $11(25 \%)$ & $9(75 \%)$ & 0.001 \\
\hline Urinary tract catheterization & $10(22.7 \%)$ & $5(41.7 \%)$ & 0189 \\
\hline Tracheostomy & $7(15.9 \%)$ & $3(25 \%)$ & 0.466 \\
\hline Total parenteral nutrition & $4(9.1 \%)$ & $3(25 \%)$ & 0.140 \\
\hline Gastric motility inhibitors & $2(6.8 \%)$ & $2(16.7 \%)$ & 0.289 \\
\hline Gastrostomy & $1(2.3 \%)$ & - & - \\
\hline Chest tube insertion & $1(2.3 \%)$ & - & - \\
\hline
\end{tabular}

\section{DISCUSSION}

Hospital associated infection was first described in 1843 by Oliver Wendell Holmes. He proposed, the fever in postpuerperal women occurred due to lack of hand hygiene of the medical stuff ${ }^{7}$. In the past decade, the term has shifted to health-care associated infection and many attempts have been 
implemented by the health care stuff to decline the nasocomial infections all over the world ${ }^{6}$.

HAI prolongs the hopitalization period and increase the health-care related expenses ${ }^{8}$. In addition of chronical underlying disease of the critically ill child, administration of widespectrum antibiotics, invasive procedures such as central venous catheterization, urinary tract catheterization, invasive mechanical ventilation and prolonged hospital admission increase the the odds of HAI ratio by 5-10 times at intensive care units $^{8,9}$.

The importance of local PICU surveillance for prevention of HAI have been well documented in 'The Study of the Efficacy of Nosocomial Infection Control and Prevention' (SENIC) ${ }^{10}$ This study demonstrated the successfull decline in nasocomial infections in presence of appropriate prevention protocols. Therefore, each health-care facility should study on their own local survaillance protocols, determine the profile of prominent microorganisms with resistant strains and arrange the antibiotherapy accordingly. We also constituted our survaillance protocol with the collaboration of the infection control committee.

Numerous articles regarding HAI rates at intensive care units in Turkey have been published over ther years ${ }^{11-14}$; however those encompassing the pediatric ICUs are limited. The HAI incidence vary greatly between $2.36 \%$ and $37 \%$ depending on the survaillance methods, health-care stuff and infection prevention protocols ${ }^{5,11-14}$. Celiloglu et al. documented the five years HAI rate as $2.36 \%$ (60/2545 patients) ${ }^{11}$; on the contrary the incidence was described as $32.7 \%$ at the report of An1l et $\mathrm{al}^{5}$, which was significantly higher than the latter .

We detected the VAP incidence as $36.6 \%$, followed by BSI $(25.4 \%)$ and CAUTI $(25.4 \%)$, SSI $(9.9 \%)$ and CLABSI $(2.8 \%)$. A point prevalance study conducted in 2015, had appointed the upper respiratroy tract infections and BSI as the most frequent HAI subgroups $(23.5 \%, 11.6 \%)^{12}$. We documented the most common source of HAI as VAP, similar to the study of Akyıldız et al ${ }^{13}$.

Pseudomonas, Klebsiella ve Acinetobacter strains have replaced $S$. Aureus by means of frequent bacterias in the past decade ${ }^{15,16}$. The results of this study were concardant with literature; we observed gram negative bacterias (77.1\%), specifically Acinetobacter baumanii (25.3\%), Klebsiella pneumonia (14.1\%) and Pseudomonas aeruginosa $(11.3 \%)$ as the prominent bacteria strains. Pseudomonas aeruginosa and Acinetobacter baumanii are responsible for majority of VAP in several studies ${ }^{12,13}$. Therefore, in case of ampiric antibiotherapy decision for moderate / severe PICU infections, the antibiotic choice should cover the gram negative bacteria with anti-pseudomonal activity.

The microorganism strains and antiobiotic resistance might change over the years. Infections with resistant strains of gram negative bacterias have an escalating trend at intensive care units ${ }^{5,11-}$ ${ }^{13}$. The antibiotic resistance occurred as $42.2 \%$ in the present study; of them $21.1 \%$ presented carbapenem resistant strains, while $12.5 \%$ had ESBL positivity. The search of the infection site for resistant strains demonstrated the carbapenemresistance mostly observed at SSI $(5 / 15,33.3 \%)$ and ESBL positivity at BSI and CAUTI equally $(16,6 \%$ for each infection site). Celiloğlu documented Pseudomonas aeruginosa and Klebsiella Pneumoniae as the most frequent bacterias with carbapenem resistance of $65 \%$ and $56 \%$ respectively ${ }^{11}$. Our observations on colistin resistant Acinetobacter baumannii infections were lower than expected $(16.6 \%)^{12,13}$. The intriquing point in the present study was the observation of resistant strains in Staphylococcus aureus (MRSA:100\%) and meticilline resistant CoNS bacterias $(50 \%)$. The rates of resistant strains at VAP were $50 \%$ for colistin-resistant Acinetobacter baumanii and $15.4 \%$ for carbapenem resistant infections.

The infection outcome over the past five years demonstrates a general incline at Colistinresistance and a decline at Carbapenem-resistance. Extensive administration of antibiotics at intensive care units results in antibiotic resistant bacteria colonization and infections. Hence, the treatment of such children have become more challenging with significant mortality rates. Despite the advances in antibiotherapy, the mortality rates are varying between $9 \%$ and $80 \%$ 11,13,14. Twelve children died of infections (HAI mortality rate: $21.4 \%$ ). Age less than five years, higher PRISM-3 score, longer intubation, frequent nasogastric tube insertion were associated with mortality in this study. The mentioned risk factors were similar to those reported in literature ${ }^{17-19}$.

\section{CONCLUSION}

Health-care associated infections remain to be a major problem all around the world. What we can do to overcome this challenge is, to initiate local survaillance protocols, educate the health-care stuff on hand hygiene, enforce appropriate 
isolation tactics and practice wise antibotic administration.

\section{REFERENCES}

1. Furue M, Kadono T. Bullous pemphigoid: What's ahead? J Dermatol. 2016 ;43:237-40.

2. Kershenovich R, Hodak E, Mimouni D. Diagnosis and classification of pemphigus and bullous pemphigoid. Autoimmun Rev. 2014;13:477-81.

3. Akay BN, Bodamyalı P, Şanlı H, Akyol A. 10-Year Observation of Bullous Pemphigoid Patients. Turkderm 2010; 44: 61-4.

4. Schmidt E, Zillikens D. Pemphigoid diseases. Lancet. 2013;381:320-32.

5. Marzano AV, Tedeschi A, Fanoni D, et al. Activation of blood coagulation in bullous pemphigoid: role of eosinophils, and local and systemic implications. $\mathrm{Br} \mathrm{J}$ Dermatol. 2009;160:266-72.

6. Bancroft AJ, Abel EW, Mclaren M, Belch JJ. Mean platelet volume is a useful parameter: a reproducible routine method using a modified Coulter thrombocytometer. Platelets. 2000;11:379-87.

7. Park Y, Schoene N, Harris W. Mean platelet volume as an indicator of platelet activation: methodological issues. Platelets 2002; 13: 301-306.

8. Polat M, Bugdayci G, Kaya H, Oğuzman H. Evaluation of neutrophil-to-lymphocyte ratio and platelet-to lymphocyte ratio in Turkish patients with chronic plaque psoriasis. Acta Dermatovenerol Alp Pannonica Adriat. 2017;26: 97-100.

9. Rifaioglu EN, Sen BB, Ekiz Ö, Dogramaci AC. Mean platelet volume and eosinophilia relationship in patients with bullous pemphigoid. Platelets.2014;25:264-7.

10. Ozer I, Balevi S, Ataseven A. Can Neutrophil/Lymphocyte Ratio Be Used As a Marker in the Diagnosis of Bullous Pemphigoid? Selcuk Med J 2018;34: 65-69.

11. Baum S, Sakka N, Artsi O, Trau H, Barzilai A. Diagnosis and classification of autoimmune blistering diseases. Autoimmun Rev 2014;13:482-9.

12. Ekiz Ö, Şen BB, Rifaioğlu EN, et al. Three-year observation of the patients with bullous pemphigoid: 29 cases. Turkderm 2013;47:205-8.

13. Yazıcı S, Başkan EB, Tunalı Ş, Aydoğan K, Sarıcaoğlu H. Kliniğimizde takip edilen kırk-altı büllöz pemfigoid olgusunun retrospektif analizi.Turkderm 2016;50:114-8.

14. Tan SK, Tay YK. Bullous pemphigoid: Profile and outcome in a series of 100 cases in Singapore. J Dermatol Dermatol Surg 2018;22:12-5.

15. Kizılyel O, Elmas ÖF, Bilen $\mathrm{H}$, et al. Bullous pemphigoid in Erzurum: A 10 year retrospective study. Turkderm 2015; 49: 66-9.

16. Ong E, Goldacre R, Hoang U, Sinclair R, Goldacre M. Associations between bullous pemphigoid and primary malignant cancers: an English national record linkage study, 1999-2011. Arch Dermatol Res 2014;306:7580.

17. Marzano AV, Tedeschi A, Spinelli D, et al. Coagulation activation in autoimmune bullous diseases. Clin Exp Immunol. 2009;158:31-6.

18. Schmidt E, Della Torre R, Borradori L. Clinical features and practical diagnosis of bullous pemphigoid. Dermatol Clin 2011;29:427-38.

19. Ameglio F, D'Auria L, Bonifati C, et al. Cytokine pattern in blister fluid and serum of patients with bullous pemphigoid: Relationships with disease intensity. $\mathrm{Br} \mathrm{J}$ Dermatol 1998;138:611-4.

20. Gökmen F, Akbal A, Reşorlu H, et al. Neutrophil-Lymphocyte Ratio Connected to Treatment Options and Inflammation Markers of Ankylosing Spondylitis. J Clin Lab Anal. 2015;29:294-8.

21. Sen BB, Rifaioglu EN, Ekiz O, et al. Neutrophil to lymphocyte ratio as a measure of systemic inflammation in psoriasis. Cutan Ocul Toxicol.2014;33:223-7. 
22. Ozturk C, Balta S, Balta I, et al. Neutrophil-lymphocyte ratio and carotidintima media thickness in patients with Behçet disease without cardiovascular involvement. Angiology. 2015;66:291-6.

23. Uçmak D, Akkurt M, Uçak H, et al. The relationship of neutrophil to lymphocyte ratio with pemphigus vulgaris. Konuralp Medical Journal 2015;2015:88-92.

24. Kridin K, Shihade W, Zelber-Sagi S. Mean Platelet Volume in Pemphigus Vulgaris. Angiology. 2018;69:303-307.

25. Canpolat F, Akpinar H, Eskioğlu F. Mean platelet volume in psoriasis and psoriatic arthritis. Clin Rheumatol. 2010;29:325-8.

26. Balkarli A, Kucuk A, Babur H, Erbasan F. Neutrophil/lymphocyte ratio and mean platelet volume in Behçet's disease. Eur Rev Med Pharmacol Sci. 2016;20:3045-50.

27. Jiang $\mathrm{Y}, \mathrm{Ma} \mathrm{W}$. Assessment of Neutrophil-to-Lymphocyte Ratio and Plateletto-Lymphocyte Ratio in Atopic Dermatitis Patients. Med Sci Monit. 2017;23:1340-1346.
28. Kim DS, Shin D, Lee MS, et al. Assessments of neutrophil to lymphocyte ratio and platelet to lymphocyte ratio in Korean patients with psoriasis vulgaris and psoriatic arthritis. J Dermatol. 2016;43:30510 .

29. Wu Y, Chen Y, Yang X, Chen L, Yang Y. Neutrophil-to-lymphocyte ratio (NLR) and platelet-to-lymphocyte ratio (PLR) were associated with disease activity in patients with systemic lupus erythematosus. Int Immunopharmacol. 2016;36:94-99.

30. Hayta SB, Güner R, Akyol M. Blood mean platelet volume may be predictive for disease course in the cases with pemphigus vulgaris. Biomedical Research 2017;28: 4223-4227. 